\title{
In Vitro Antimicrobial Activity of Acroseal, Polifil and Epiphany against Enterococcus faecalis
}

\author{
Cláudia Ramos PINHEIRO ${ }^{1}$ \\ Adriana Simionatto GUINESI ${ }^{1}$ \\ Antônio Carlos PIZZOLITTO² \\ Idomeo BONETTI-FILHO ${ }^{1}$ \\ ${ }^{1}$ Department of Restorative Dentistry, Araraquara Dental School, São Paulo State University, Araraquara, SP, Brazil \\ ${ }^{2}$ Departament of Clinical Analysis, School of Pharmaceutical Sciences, \\ São Paulo State University, Araraquara, SP, Brazil
}

\begin{abstract}
Using the agar diffusion method, this study evaluated the in vitro antimicrobial activity of the commercial endodontic sealers Acroseal and Epiphany, a castor-oil based experimental sealer, Polifil, and a primer agent (Epiphany self-etching primer), against Enterococcus faecalis. Zinc oxide and eugenol cement (ZOE) served as control. Five wells per dish were made at equidistant points and immediately filled with the test and control materials. After incubation of the dishes at $37^{\circ} \mathrm{C}$ for $24 \mathrm{~h}$ and $48 \mathrm{~h}$, the diameter of the zones of microbial growth inhibition produced around the wells was measured (in $\mathrm{mm}$ ) with a millimeter rule. After $48 \mathrm{~h}$, the diameters of the zones of microbial growth inhibition were the same as those observed at $24 \mathrm{~h}$, only the substances continued to diffuse. Epiphany and Polifil did not show antibacterial activity (no formation of zones of microbial growth inhibition). The primer produced the largest zones of inhibition $(17.62 \mathrm{~mm})$ followed by Acroseal $(7.25 \mathrm{~mm})$ and ZOE $(7.12 \mathrm{~mm})$. E. faecalis was resistant to Epiphany and Polifil, while the primer and Acroseal sealer were effective against this microorganism under the tested conditions.
\end{abstract}

Key Words: antibacterial activity, endodontic sealers, in vitro study.

\section{INTRODUCTION}

Successful root canal treatment requires proper cleaning and shaping of the root canal system, as well as hermetic sealing of the canal space with an inert, dimensionally stable and biologically compatible material (1). Therefore, the search continues for an endodontic sealer that fulfills the requirements for the ideal physicochemical and biological properties.

Bacteria are the main causative factor in the development of periapical inflammation (2). The main objective of endodontic therapy is, thus, to eliminate bacteria from infected root canals and to prevent reinfection. Complete chemomechanical preparation remains an important step in root canal disinfection; however, careful obturation is essential to avoid reinfection of the root canal space.

The use of improved calcium hydroxide-based "biological" sealers has been proposed for permanent seal of the root canal system (3). Calcium hydroxidecontaining compounds have an excellent bactericidal action because of their high $\mathrm{pH}$ (4), mediate degradation of bacterial lipopolysaccharides (5), induce healing by hard tissue formation (6) and control inflammatory root resorption (3), being widely used and recommended in root canal therapy. Several endodontic sealers containing calcium hydroxide in their formulations are commercially available, among which Apexit, CRCS and Sealer 26. Recently, a new calcium hydroxide-based sealer, Acroseal, has been introduced to the market (7).

Resin-based root canal filling materials have steadily gained popularity and are now accepted both for anterior and posterior teeth. The bonding systems have improved, which explains the resistance of some materials to bacterial penetration (8). A thermoplastic synthetic resin polymer, Resilon/Epiphany system [(RES); Pentron Clinical Technologies, LLC Wallingford, CT, USA], has recently emerged as a promising root canal obturation

Correspondence: Prof. Dr. Idomeo Bonetti Filho, Departamento de Odontologia Restauradora, Faculdade de Odontologia de Araraquara, UNESP, Rua Humaitá, 1680, 331, 14801-903 Araraquara, SP, Brasil. Tel: +55-16-3301-6388/6393. e-mail: idomeo@foar.unesp.br 
material and has gained popularity among endodontists and general dentists (9). Resilon core material is used with Epiphany dual cured resin sealer and self-etching primer, and this combination purportedly forms a single entity or monoblock in the root canal system $(9,10)$. The sealer Epiphany has been shown to be noncytotoxic, biocompatible and nonmutagenic, has been approved for endodontic use by the FDA, and has been claimed to be more resistant to leakage than gutta-percha-based obturation systems (9). Before using this sealer, the manufacturer recommends the use of a primer.

Dentin primers are used in restorative dentistry and endodontics when a resin sealer is employed. The adhesive and primer properties have been studied (11) and their antibacterial activity has been tested in vitro against a number of bacterial species (12). However, further in vitro and in vivo research is needed to determine the clinical significance and duration of these antibacterial properties against the wide variety of microorganisms that may be present in the oral cavity and endodontic infections.

In 1984, Professor Gilberto O. Chierice, from the Institute of Chemistry of São Carlos, University of São Paulo, Brazil, developed a substance extracted from Ricinus communis (castor-oil), which brought successful outcomes in Medicine. This substance has also dental applications due to its properties of biocompatibility and antimicrobial activity (13). A castor-oil- based experimental sealer (Polifil) has been developed at Araraquara Dental School, São Paulo State University, Brazil, and its physicochemical and biologic properties have been investigated.

Enterococcus faecalis has long been implicated in persistent root canal infections and more recently has been identified as the species most commonly recovered from root canals of teeth with post-treatment disease (14). This study evaluated, using the agar diffusion method, the in vitro antimicrobial activity of Acroseal, Epiphany, Polifil and a primer agent against $E$. faecalis.

\section{MATERIAL AND METHODS}

For the agar diffusion test (double layer agarwell technique), a base layer composed of $10.0 \mathrm{~mL}$ of brain heart infusion (BHI) agar (Difco, Detroit, MI, USA) with addition of $2 \%$ bacteriological agar (Difco) was poured into $20 \times 100 \mathrm{~mm}$ sterile Petri dishes. After solidification, the plates were taken to an incubator at $37^{\circ} \mathrm{C}$ for $24 \mathrm{~h}$ to check for sterility.

E. faecalis ATCC 29212 was reactivated from lyophilized stock frozen stock for observation of cell and colony morphology, which confirmed the culture purity. The microorganism was reactivated by 3 transferences in BHI broth (Difco) followed by incubation at $37^{\circ} \mathrm{C}$ for $24 \mathrm{~h}$. For the inoculum, the culture in BHI broth incubated at $37^{\circ} \mathrm{C}$ for a period of 15 to $18 \mathrm{~h}$ was used to standardize the final concentration of $1.5 \times 10^{8}$ cells $/ \mathrm{mL}$ equivalent to the 0.5 standard of the McFarland scale using a 630-nm-wavelength spectrophotometer (Pharmacia Biotech, São Paulo, SP, Brazil).

Immediately after removal from the incubator, the bacterial inocula were seeded with cotton sticks all over the dishes, based on the McFarland scale, using Trypticasein Soy Broth (TSB), except for one plate in which E. faecalis was not seeded (negative control). The study evaluated the antimicrobial activity of the following materials:

Group I: Epiphany (endodontic sealer) (Pentron Clinical Technologies, Wallingford, CT, USA) - mixture of UDMA, Pegdma, Ebpadma, silane-treated barium borosilicate glasses, barium sulfate, silica, calcium hydroxide, bismuth oxycloride with amines, peroxide, photo initiator, stabilizers and pigment.

Group II: primer agent (Epiphany self-etching primer - Pentron Clinical Technologies) - TEGDMA, acetone, photoinitiators.

Group III: Acroseal (endodontic sealer) (Septodont, Saint Maur des Fosses, France) - Base: Calcium hydroxide, DGEBA (diglycidyl ether of bisphenol A) and radiopaque excipient. Activator: Glycyrrhetic acid (enoxolone) methenamine and radiopaque excipient.

Group IV: Polifil (endodontic sealer) (Araraquara Dental School, São Paulo State University, Araraquara, SP, Brazil) - Calcium carbonate, polyol, zinc oxide and eugenol.

Group V: Zinc oxide and eugenol cement (positive control) (SS White, Rio de Janeiro, RJ, Brazil).

After solidification of the seed layer, five $6 \times 4$ $\mathrm{mm}$ wells were made in each dish by removal of the agar at equidistant points using a sterile straw, and were immediately filled with the test and control materials (one well for each substance). The commercial materials were mixed according to the manufacturers' instructions. Epiphany is supplied in individual tubes with a tip that mixes the sealer components at the moment of use. The mixed material was carefully placed inside the 
wells with aid of 2 Hollenbeck sculptors. The other cements were mixed at 1:1 ratio of the components before insertion in the wells: Acroseal, supplied in 1-cm-long tubes (base and activator), Polifil, supplied in 2 plastic syringes ( 1 containing polyol and the other containing calcium carbonate), and zinc oxide and eugenol, supplied as powder and liquid components. For the primer agent, 1 drop was dripped per well. Eight repetitions of the test were done, that is, 8 plates were used for the test microorganism.

After placement of the materials, $15.0 \mathrm{~mL}$ of BHI agar was poured on each dish and were kept at room temperature for $2 \mathrm{~h}$ for pre-diffusion of the material and then incubated at $37^{\circ} \mathrm{C}$ for 24 up to $48 \mathrm{~h}$. After the initial $24 \mathrm{~h}$, the zones of microbial growth inhibition around the wells were measured with a millimeter ruler with $0.5-\mathrm{mm}$ accuracy. The dishes were incubated again and new measurements were done after $48 \mathrm{~h}$. As the diameters of the zones of microbial growth inhibition at $48 \mathrm{~h}$ were the same as those measured at $24 \mathrm{~h}$, only the substances continued to diffuse, only the 24 -h values were considered for the study.

No statistical analysis was done in this study due to the different diffusibility of substances tested in agar. Since the diameter of the inhibition zone does not necessarily reflect the efficacy of the antimicrobial agent, the activity of each material was evaluated considering the presence or absence of inhibition zone, as previously reported by Sipert et al. (15).

\section{RESULTS}

The means and standard deviations of the zones of microbial growth inhibition (in $\mathrm{mm}$ ) for each substance tested against $E$. faecalis within a 24 -h period were: Epiphany: 0.00, Primer: $17.62 \pm 2.26$, Acroseal: 7.25 \pm 0.46 , Polifil: 0.00 , ZOE: $7.12 \pm 0.64$

Epiphany and Polifil did not show antibacterial activity (no zones of microbial growth inhibition). The primer produced the largest zones of inhibition (17.62 $\mathrm{mm}$ ) followed by Acroseal $(7.25 \mathrm{~mm})$ and ZOE (7.12 $\mathrm{mm})$. E. faecalis was resistant to Epiphany and Polifil, while the primer and Acroseal sealer were effective against this microorganism under the tested conditions.

\section{DISCUSSION}

In addition to eliminating microorganisms that have been left behind after chemomechanical preparation, a filling material should prevent recolonization of the root canal system (16).

The agar diffusion method has been widely employed to investigate the antimicrobial activity of dental materials, however; this procedure does not depend only on the material toxicity to a given microorganism, but may also be influenced by the diffusion and affinity of the material in the culture medium. A material presenting easier diffusion will produce larger zones of inhibition of bacterial growth (15).

Epiphany's manufacturer claims state that this dual-cure, resin root canal sealer is non-mutagenic, non-cytotoxic, biocompatible and less irritating than epoxy resin or zinc oxide and eugenol-based sealers (9). According to some authors $(9,10)$, this sealer has a great sealing capacity of the root canal walls, but little research-based information is available about its antibacterial activity.

The results obtained in the present study show that Epiphany had no antibacterial activity against $E$. faecalis since there was no inhibition zone formation. This result partly agrees with the findings of a previous study (17) that investigated the antibacterial efficacy of Endomethasone, Sultan, Sealapex, Diaket, Epiphany and AH 26 against $E$. faecalis using the agar diffusion method and found that all sealers caused bacterial growth inhibition. Their effectiveness, in a descending order of antimicrobial activity, was as follows: Endomethasone, Sultan, Sealapex, Diaket, Epiphany and AH 26. Epiphany had little effect against the tested microorganism and the authors concluded that it offered no antibacterial advantage over the other tested sealers.

The Epiphany self-etching primer is used to condition the canal walls for bonding to the Epiphany sealer. The primer is composed of PENTA, TEGDMA, acetone and photoinitiators. In the present study, the primer was tested alone, apart from Epiphany sealer, showing the largest inhibition zones against $E$. faecalis $(17.62 \mathrm{~mm})$. However, our results disagree from those of Herrera et al. (11), who evaluated the antibacterial activity of bonding systems Gluma 2000, Syntac, Prisma Universal Bond 3, Scotchbond Multipurpose and PrimeBond against 32 strains of the caries-producing bacteria Streptococcus spp., Lactobacillus spp., Actinomyces spp., Porphyromonas spp. and Clostridium spp. An agar diffusion method was used with chlorhexidine as the positive control. The tests were performed in triplicate 
for each component (primer and adhesive) of the bonding systems. All the adhesives were found to inhibit bacterial growth but with differences in their spectra of action. The sum action of the Scotchbond Multipurpose components was most inhibitory and Prime-Bond was found to be the least effective system.

Acroseal is a calcium hydroxide-based sealer. Calcium hydroxide has been used in endodontic therapy for a long time due to its antimicrobial property, ability to induce formation of hard tissue when placed in the root canal system, alkaline $\mathrm{pH}$ (12.5) and dissociation into calcium and hydroxyl ions, which make the environment unfavorable to bacterial proliferation (3-6). Acroseal was effective against the test microorganism with formation of a zone of microbial growth inhibition $(7.25 \mathrm{~mm})$. This is partly in agreement with the study Eldeniz et al. (7), who used a different methodology from that of present study. The authors evaluated the $\mathrm{pH}$ and calcium ion release of three calcium hydroxide-based sealers (Acroseal, Apexit and Sealapex) as well as the time required to kill microorganisms (among them $E$. faecalis). The authors concluded that Acroseal sealer presented less calcium ion release and $\mathrm{pH}$ than Apexit and less calcium ion release when compared to Sealapex, lasting to kill all the microorganisms. Further research should be done in order to investigate the antibacterial activity of Acroseal as little information is available.

Arecent study (18) reported that Polifil is efficient on sealing the root canal walls when compared to other endodontic sealers. However, in the present study, Polifil had no antibacterial activity against $E$. faecalis since there was not inhibition zone formation, which can be justified by the difficulty of the oil vehicle present in this substance to diffuse though the agar. There is no other study evaluating the antimicrobial activity of this sealer so far. Using the agar diffusion test (double layer agar-well technique), Leonardo et al. (19) studied the antimicrobial activity of some irrigating solutions: Endoquil (castor oil detergent), $2 \%$ chlorhexidine gluconate solution, and $0.5 \% \mathrm{NaOCl}$ solution against gram-positive cocci (Micrococcus luteus, Staphylococcus aureus, E. faecalis, Staphylococcus epidermidis, Streptococcus mutans and Streptococcus sobrinus), gram-negative rods (Escherichia coli and Pseudomonas aeruginosa) and the yeast Candida albicans. Absorbent 6.0-mm-diameter paper discs immersed in the solutions were placed at equidistant points. The dishes were maintained at room temperature for $2 \mathrm{~h}$ for pre-diffusion of the solutions and incubated at $37^{\circ} \mathrm{C}$. The candle jar system was used for the BHI agar plates. After incubation, the zones of microbial growth inhibition were measured. All bacterial strains were inhibited by $2 \%$ chlorhexidine gluconate. Endoquil was effective against gram-positive microorganisms, and $0.5 \% \mathrm{NaOCl}$ was effective only against $S$. aureus.

ZOE presented antimicrobial activity $(7.12 \mathrm{~mm})$ against the bacterial tested $(15,20)$ because the zinc oxide and eugenol components diffuse through the Muller Hinton agar, and is frequently used as a positive control in studies with this type of methodology.

Thus, in this study, E. faecalis was resistant to Epiphany and Polifil sealers. The primer and the Acroseal sealer were effective against the target microorganism, under the tested conditions.

\section{RESUMO}

Utilizando o método de difusão em ágar, este estudo avaliou in vitro a atividade antimicrobiana dos cimentos endodônticos comerciais: Acroseal e Epiphany, um cimento experimental à base do polímero da mamona, Polifil, e um agente primer (primer auto-adesivo do sistema Epiphany), contra Enterococcus faecalis. O cimento de óxido de zinco e eugenol (OZE) serviu como controle. Cinco poços por placa foram feitos em pontos eqüidistantes e imediatamente preenchidos com os materiais testados e controle. Após a incubação das placas aos $37^{\circ} \mathrm{C}$ por $24 \mathrm{e} 48 \mathrm{~h}$ foram medidas as zonas de inibição do crescimento bacteriano ao redor dos poços (em mm) com uma régua milimetrada. Após 48 h, os diâmetros das zonas de inibição do crescimento bacteriano foram os mesmos observados às $24 \mathrm{~h}$, apenas as substâncias continuaram a se difundir. Epiphany e Polifil não apresentaram atividade antibacteriana (não ocorreu a formação das zonas de inibição do crescimento bacteriano). Os maiores halos de inibição foram atribuídos ao primer (17,62 mm), seguido do Acroseal (7,25 mm) e OZE (7,12 $\mathrm{mm})$. E. faecalis foi resistente ao Epiphany e Polifil, enquanto que o primer e o cimento Acroseal foram eficientes contra esse microrganismo nas condições testadas.

\section{ACKNOWLEDGEMENTS}

The authors wish to thank Professor Antônio Carlos Pizzolitto for the experience shared. We also want to thank Maria do Carmo Dória Martins for the dedication and friendship.

\section{REFERENCES}

1. Scarparo RK, Grecca FS, Fachin EV. Analysis of tissue reactions to methacrylate resin-based, epoxy resin-based, and zinc oxideeugenol endodontic sealers. J Endod 2009;35:229-232.

2. Siqueira JF Jr, Rôças IN. Bacterial pathogenesis and mediators in apical periodontitis. Braz Dent J 2007;18:267-280.

3. JOE Editorial Board. Uses of calcium hydroxide: an online study guide. J Endod 2008;34:87-84. 
4. Byström A, Claesson R, Sundqvist G. The antibacterial effect of camphorated paramonochlorophenol, camphorated phenol and calcium hydroxide in the treatment of infected root canals. Endod Dent Traumatol 1985;1:170-175.

5. Safavi KE, Nichols FC. Effect of calcium hydroxide on bacterial lipopolysaccharide. J Endod 1993;19:76-78.

6. Soares I, Goldberg F, Massone EJ, Soares IM. Periapical tissue response to two calcium hydroxide-containing endodontic sealers. J Endod 1990;16:166-169.

7. Eldeniz AU, Erdemir A, Kurtoglu F, Esener T. Evaluation of pH and calcium ion release of Acroseal sealer in comparison with Apexit and Sealapex sealers. Oral Surg Oral Med Oral Pathol Oral Radiol Endod 2007;103:86-91.

8. Hilton TJ. Can modern restorative procedures and materials reliably seal cavities? In vitro investigations. Part 1. Am J Dent 2002;15:198-210.

9. Shipper G, Orstavik D, Teixeira FB, Trope M. An evaluation of microbial leakage in roots filled with a thermoplastic synthetic polymer-based root canal filling material (Resilon). J Endod 2004;30:342-347.

10. Shipper G, Teixeira FB, Arnold RR, Trope M. Periapical inflammation after coronal microbial inoculation of dog roots filled with gutta-percha or Resilon. J Endod 2005;31:91-96.

11. Herrera M, Carrion P, Bravo M, Castillo A. Antibacterial activity of four dentin bonding systems. Int J Antimicrob Agents 2000;15:305-309.

12. Fraga RC, Sigueira JF, De Uzeda M. In vitro evaluation of antibacterial effects of photo-cured glass ionomer liners and dentin bonding agents during setting. J Prosthet Dent 1996;76:483-486.

13. Ferreira CM, Calixto RFE. Activity of endodontic antibacterial agents against selected anaerobic bacteria. Braz Dent J 2002;13:118-122.

14. Pirani C, Bertacci A, Cavrini F, Foschi F, Acquaviva GL, Prati C, et al.. Recovery of Enterococcus faecalis in root canal lumen of patients with primary and secondary endodontic lesions. New Microbiol 2008;31:235-240.

15. Sipert CR, Hussne RP, Nishiyama CK, Torres SA. In vitro antimicrobial activity of Fill Canal, Sealapex, Mineral Trioxide Aggregate, Portland cement and EndoRez. Int Endod J 2005;38:539-543.

16. Baumgartner G, Zehnder M, Paqué F. Enterococcus faecalis type strain leakage through root canals filled with gutta-percha/AH Plus or Resilon/Epiphany. J Endod 2007;33:45-47.

17. Bodrumlu E, Semiz M. Antibacterial Activity of a New Endodontic Sealer against Enterococcus faecalis. J Can Dent Assoc 2006;72:637-640.

18. Souza EM, Pappen FG, Shemesh H, Bonanato-Estrela C, Bonetti Filho I. Reliability of assessing dye penetration along root canal fillings using methylene blue. Aust Endod J 2009 [In press].

19. Leonardo MR, da Silva LA, Tanomaru Filho M, Bonifacio KC, Ito IY. In vitro evaluation of the antimicrobial activity of a castor oil-based irrigant. J Endod 2001;27:717-719.

20. Saleh IM, Ruyter IE, Ørstavik D, Haapasalo M. Survival of Enterococcus faecalis in infected dentinal tubules after root canal filling with different root canal sealers in vitro. Int Endod J 2004;37:193-198. 